\title{
Patterns of genetic divergence among populations of the pseudometallophyte Biscutella laevigata from southern Poland
}

\author{
Alicja A. Babst-Kostecka • Christian Parisod • \\ Cécile Godé • Pierre Vollenweider • Maxime Pauwels
}

Received: 4 April 2014 / Accepted: 6 June 2014 / Published online: 19 June 2014

(C) The Author(s) 2014. This article is published with open access at Springerlink.com

\begin{abstract}
Background and aims Pseudometallophytes are model organisms for adaptation and population differentiation because they persist in contrasting edaphic conditions of metalliferous and non-metalliferous habitats. We examine patterns of genetic divergence and local adaptation of Biscutella laevigata to assess historical and evolutionary processes shaping its genetic structure.

Methods We sampled all known populations of B. laevigata in Poland and analyzed respective soil metal concentrations. For genotyping we used nine nuclear
\end{abstract}

Responsible Editor: Erik J. Joner.

Electronic supplementary material The online version of this article (doi:10.1007/s11104-014-2171-0) contains supplementary material, which is available to authorized users.

\section{A. A. Babst-Kostecka $(\bowtie)$ \\ Institute of Botany Polish Academy of Sciences, \\ Lubicz 46, 31512 Krakow, Poland \\ e-mail: a.kostecka@botany.pl}

\begin{abstract}
A. A. Babst-Kostecka • C. Godé • M. Pauwels Laboratoire de Génétique et Evolution des Populations Végétales, FRE CNRS 3268, Université de Lille-Lille1, 59655 Villeneuve d'Ascq, France
\end{abstract}

\section{A. A. Babst-Kostecka • P. Vollenweider}

Swiss Federal Institute for Forest,

Snow and Landscape Research WSL,

Zürcherstrasse 111, 8903 Birmensdorf, Switzerland

C. Parisod

Laboratory of Evolutionary Botany, Institute of Biology, University of Neuchâtel,

2000 Neuchâtel, Switzerland microsatellite loci. Population genetic pools were identified (Bayesian clustering) and we estimated genetic parameters and demographic divergence between metallicolous and non-metallicolous populations (ABCapproach).

Results Populations clustered into two groups which corresponded to their edaphic origin and diverged 1,200 generations ago. We detected a significant decrease in genetic diversity and evidence for a recent bottleneck in metallicolous populations. Genetic structure was unrelated to site distribution but is rather influenced by environmental conditions (i.e. soil metal concentration).

Conclusions The intriguing disjunctive distribution of B. laevigata in Poland results from a fragmentation of the species range during the Holocene, rather than recent long-distance-dispersal events. The genetic structure of populations, however, continues to be modified by microevolutionary processes at anthropogenic sites. These clear divergence patterns promote B. laevigata as a model species for plant adaptation to polluted environments.

Keywords Adaptation - Biogeography - Genetic structure $\cdot$ Metal trace elements $\cdot$ Pollution $\cdot$ Relic

\section{Introduction}

The adaptation of organisms to natural and/or anthropogenic changes in their physical environment has raised considerable interest among plant ecologists and evolutionary biologists. Special attention has been given to living organisms occurring on sites with high 
concentrations of Metal Trace Elements (hereafter called "metals"). Most organisms are unable to cope with such harsh environmental conditions, but some plant species manage to colonize, develop, and reproduce in metal polluted habitats. Those species are thus defined as metal tolerant (Macnair 1987). Metal tolerance may have evolved on either naturally metalenriched soils or on anthropogenic sites that have been generated by waste deposits from ore mining or metal smelter activity (Ernst et al. 1990; Peralta-Videa et al. 2009). In contrast to natural metalliferous soils, industrial sites are younger and generally show higher metal concentrations. These differences in site history may affect the evolutionary processes and selection pressure dynamics. Adaptation is expected to evolve faster on artificially polluted sites, but with large differences observed between taxa (Ernst 2006). Hence, the evolution of metal tolerance on anthropogenic contaminated soils has been extensively studied for more than half a century to better understand plant adaptation to restrictive environments over ecological times (Antonovics et al. 1971; Linhart and Grant 1996).

Plants occurring on metal contaminated soils usually belong to pseudometallophyte species developing both metallicolous ( $\mathrm{M}$, on metal-enriched soils) and nonmetallicolous populations (NM, on non-polluted soils; Lambinon and Auquier 1964). Such contrasting edaphic types are expected to be genetically distinct (Macnair et al. 2000). Firstly, local adaptation to metal-polluted soils is expected to result in a higher frequency of tolerant genotypes in M compared to NM populations. Accordingly, several phenotyping experiments reported higher mean metal tolerance levels in $\mathrm{M}$ compared to NM populations (e.g. Assunção et al. 2003; Meyer et al. 2010; Pauwels et al. 2006). Secondly, considering that $\mathrm{M}$ populations of pseudometallophyte species occurring on anthropogenic polluted sites result from recent colonization and adaptation events, their level of neutral genetic diversity is expected to be reduced due to selection, founder and bottleneck effects during the colonization of metalliferous soils (Lefèbvre and Vernet 1990; $\mathrm{Wu}$ 1990). This rationale has been confirmed in several studies (Deng et al. 2007; Mengoni et al. 2001; Meyer et al. 2010; Nordal et al. 1999; Wojcik et al. 2013). Other investigations, however, found comparable levels of neutral genetic variability in both $\mathrm{M}$ and NM populations (Baumbach and Hellwig 2007; Bizoux et al. 2008; Pauwels et al. 2005), or even slightly higher level within the M group (Słomka et al. 2011). Such contrasting patterns suggest that a simple comparison of edaphic types may not be sufficient to understand the structure of genetic diversity within and among populations of pseudometallophyte species. Additional factors that could influence the overall level of genetic diversity should be considered, including i) the age of polluted sites, ii) the level of soil metal concentration and associated selective pressure, iii) the level of genetic connectivity between $\mathrm{M}$ and NM populations, iv) the possibility of successive colonization events from adjacent NM populations, and v) some species-specific features such as clonal growth, sensitivity to abiotic stress, and constitutive (i.e. species wide) or population-specific metal tolerance (Bickham et al. 2000; Kang and Chung 2000; Vekemans and Hardy 2004). So far it has remained largely unclear whether historical, ecological or biogeographic factors could influence the pattern of genetic structure among $\mathrm{M}$ and NM populations of pseudometallophytes (Ye et al. 2012).

Southern Poland with its mining sites and abundance of metal tolerant species is an ideal location to study factors influencing pseudometallophyte population genetics (Zając 1996). Mining and processing of rich zinclead $(\mathrm{Zn}-\mathrm{Pb})$ ore in the Bolesław - Olkusz region (Cracow - Silesian Upland) dating back to the 13th century has created some of the largest and most polluted anthropogenic metalliferous sites in Europe, with waste heaps and dust deposits of different age, composition and metal concentrations (Cabala et al. 2009). A specific calamine flora (Grodzinska et al. 2000) has evolved in response to the selection pressure from elevated metal concentrations $(\mathrm{Zn}, \mathrm{Pb}, \mathrm{Cd})$ in soils. The majority of calamine species are native and widespread in the area surrounding the heaps (JędrzejczykKorycińska 2006). For those species, M populations can reasonably be assumed to derive from neighboring NM populations (Grodzinska et al. 2000). However, calamine flora also includes mountain species that in lowland areas occur almost exclusively on polluted soils (Grodzinska et al. 2000; Zając 1996). As a result, the distribution of such species is highly disjunctive and the closest NM populations are located $\sim 100 \mathrm{~km}$ away in the Tatra Mts. Under such circumstances, lowland M populations may either result from long distance dispersal (LDD) events postdating pollution or represent relic populations from a formerly larger distribution range prior to the Last Glacial Maximum (LGM). Either way, the genetic exchange between $\mathrm{M}$ and NM populations must be strongly limited. 
Biscutella laevigata L. (Brassicaceae) is a typical but poorly investigated pseudometallophyte, which is present in the metal-polluted habitats of southern Poland (Wóycicki 1913). Its ability to tolerate large amounts of some metals in foliar tissues (Pošćić et al. 2013) shows an interesting potential as a model species to study the adaptive colonization of metalliferous sites. This adaptive potential and tolerance to stressing ecological conditions were previously demonstrated for serpentine alpine populations (Gasser 1986). Biscutella laevigata is a perennial, strictly outcrossing species (Olowokudejo and Heywood 1984) which is widespread across Central and Western Europe and reaches its northern distribution limit in Poland (Jalas et al. 1996; Tremetsberger et al. 2002). There, B. laevigata has a clearly disjunctive distribution. It is mostly present on non-metalliferous sites in the Western Tatra Mts. However, it also grows on calamine waste heaps (i.e. metalliferous sites) in the Bolesław - Olkusz region, located $\sim 100 \mathrm{~km}$ north of this mountain range. Furthermore, one occurrence on a nonmetalliferous lowland site in Zagórzyce (Przemyski and Piwowarczyk 2012; subsequently referred to as PL10) has recently been mentioned. Populations from both the lowland waste heap sites and the Tatra Mts have been identified as diploids $(2 n=18)$ in a caryological study (Skalińska 1950) and varied in morphological and physiological traits, as well as metal tolerance levels (Wierzbicka and Pielichowska 2004). It has remained unclear, however, whether lowland populations result from relatively recent LDD events or if they are glacial relic.

In the present study, we investigated the genetic variability of $B$. laevigata among all 16 known low and high elevation provenances from locations in southern Poland, where highly variable metal concentrations in soil were reported (Szarek-Łukaszewska and Niklińska 2002; Babst-Kostecka et al. in review). We surveyed the nuclear genome diversity to examine population-level microevolutionary processes in the context of environmental and geographic variation. The specific aims of this study were to i) assess the genetic variability of $B$. laevigata, ii) compare patterns of genetic diversity among populations growing on recent (anthropogenic) and ancient (natural) habitats to test for a reduction in genetic variability after colonization of polluted areas, and iii) evaluate a demographic scenario and the timing of divergence between $\mathrm{M}$ and NM populations. By addressing these points, our study provides new insight into the origin and biogeographic characteristics of $\mathrm{M}$ and $\mathrm{NM}$ populations of pseudometallophyte species.

\section{Materials and methods}

Sampling and chemical analysis

Leaf material from 522 diploid individuals was sampled every $3 \mathrm{~m}$ along $100 \mathrm{~m}$ long transects at all of the 16 known (sub-)alpine locations of $B$. laevigata in the Tatra Mts (i.e. sites PL8, PL9, PL11-PL13, SK14, SK15, PL16) and their northern foothills (PL1-PL7, PL10; Fig. 1 and Table 1). Locations were categorized as

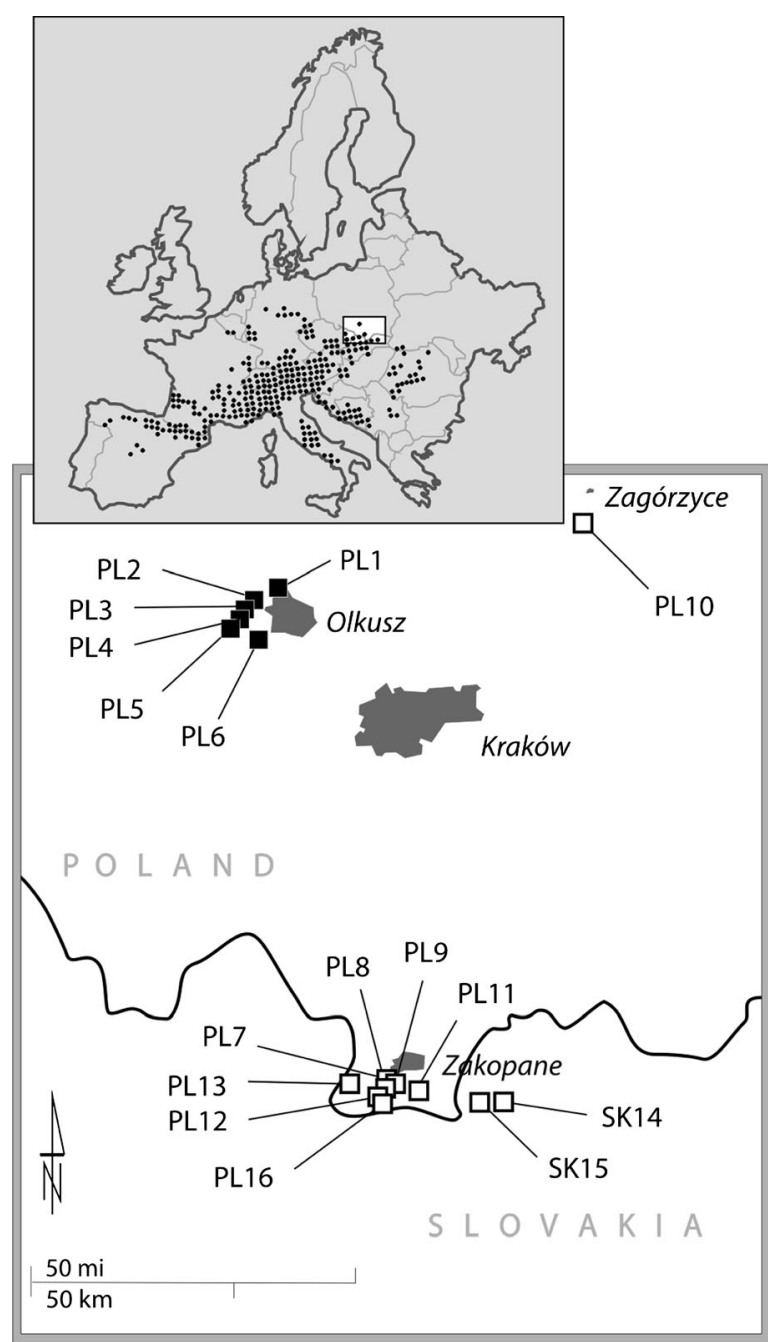

Fig. 1 Location of study sites. Open and closed squares represent sites from non-industrial and industrial areas 
Table 1 Geographic location, soil $\mathrm{pH}$ and mean extractable $\mathrm{Zn}, \mathrm{Pb}, \mathrm{Cd}$ concentrations ( $\mathrm{mg} \mathrm{kg}^{-1}, n=5$ soil samples) at the study sites

\begin{tabular}{|c|c|c|c|c|c|c|c|c|c|c|}
\hline Site & Type & Location & Latitude N & Longitude E & Altitude a.s.l.(m) & $\mathrm{pH}$ & $\mathrm{Zn}_{\mathrm{E}}$ & $\mathrm{Pb}_{\mathrm{E}}$ & $\mathrm{Cd}_{\mathrm{E}}$ & $n$ \\
\hline PL1 & M & Olkusz $(40-50)$ & $50^{\circ} 17^{\prime} 23.10^{\prime \prime}$ & $19^{\circ} 32^{\prime} 09.93^{\prime \prime}$ & 345 & 7.9 & $4,005 \pm 1,697$ & $1,203 \pm 467$ & $97.1 \pm 57.3$ & 28 \\
\hline PL2 & M & Olkusz (20-30) & $50^{\circ} 17^{\prime} 34.45^{\prime \prime}$ & $19^{\circ} 29^{\prime} 01.95^{\prime \prime}$ & 304 & 8.2 & $3,426 \pm 1,128$ & $1,317 \pm 850$ & $39.1 \pm 9.8$ & 29 \\
\hline PL3 & M & Olkusz (20) & $50^{\circ} 17^{\prime} 29.25^{\prime \prime}$ & $19^{\circ} 29^{\prime} 18.41^{\prime \prime}$ & 306 & 8.1 & $3,281 \pm 799$ & $1,152 \pm 348$ & $39.5 \pm 14.4$ & 30 \\
\hline PL4 & M & Olkusz (40-50) & $50^{\circ} 17^{\prime} 23.08^{\prime \prime}$ & $19^{\circ} 28^{\prime} 22.79^{\prime \prime}$ & 332 & 8.1 & $3,608 \pm 756$ & $541 \pm 304$ & $65.2 \pm 26.5$ & 30 \\
\hline PL5 & M & Olkusz (>100) & $50^{\circ} 17^{\prime} 28.43^{\prime \prime}$ & $19^{\circ} 28^{\prime} 14.63^{\prime \prime}$ & 319 & 7.7 & $5,569 \pm 1,811$ & $2,308 \pm 1,142$ & $126.7 \pm 59.1$ & 30 \\
\hline PL6 & M & Olkusz (na) & $50^{\circ} 17^{\prime} 06.74^{\prime \prime}$ & $19^{\circ} 27^{\prime} 59.27^{\prime \prime}$ & 338 & 7.8 & $5,922 \pm 2,327$ & $425 \pm 159$ & $65.4 \pm 16.7$ & 30 \\
\hline PL7 & NM & Tatra Mts PL & $49^{\circ} 15^{\prime} 20.75^{\prime \prime}$ & $19^{\circ} 55^{\prime} 53.73^{\prime \prime}$ & 1,258 & 7.7 & $50 \pm 21$ & $30 \pm 14$ & $1.5 \pm 0.5$ & 37 \\
\hline PL8 & NM & Tatra Mts PL & $49^{\circ} 15^{\prime} 05.63^{\prime \prime}$ & $19^{\circ} 54^{\prime} 37.62^{\prime \prime}$ & 1,342 & 7.7 & $73 \pm 38$ & $48 \pm 19$ & $1.7 \pm 0.7$ & 36 \\
\hline PL9 & $\mathrm{NM}$ & Tatra Mts PL & $49^{\circ} 15^{\prime} 40.27^{\prime \prime}$ & $19^{\circ} 57^{\prime} 01.14^{\prime \prime}$ & 1,283 & 7.7 & $60 \pm 21$ & $52 \pm 17$ & $1.8 \pm 0.4$ & 31 \\
\hline PL10 & NM & Zagórzyce & $50^{\circ} 25^{\prime} 19.20^{\prime \prime}$ & $20^{\circ} 29^{\prime} 40.98^{\prime \prime}$ & 223 & 8.0 & $11 \pm 4$ & $10 \pm 3$ & $0.5 \pm 0.1$ & 31 \\
\hline PL11 & $\mathrm{NM}$ & Tatra Mts PL & $49^{\circ} 15^{\prime} 21.46^{\prime \prime}$ & $19^{\circ} 59^{\prime} 28.22^{\prime \prime}$ & 1,241 & 7.7 & $52 \pm 18$ & $46 \pm 18$ & $1.4 \pm 0.6$ & 36 \\
\hline PL12 & NM & Tatra Mts PL & $49^{\circ} 14^{\prime} 28.48^{\prime \prime}$ & $19^{\circ} 53^{\prime} 28.37^{\prime \prime}$ & 1,712 & 7.5 & $117 \pm 63$ & $42 \pm 26$ & $2.3 \pm 0.7$ & 32 \\
\hline PL13 & $\mathrm{NM}$ & Tatra Mts PL & $49^{\circ} 16^{\prime} 11.10^{\prime \prime}$ & $19^{\circ} 48^{\prime} 39.02^{\prime \prime}$ & 1,029 & 7.5 & $72 \pm 20$ & $57 \pm 23$ & $1.8 \pm 0.5$ & 33 \\
\hline SK14 & $\mathrm{NM}$ & Tatra Mts SK & $49^{\circ} 13^{\prime} 57.22^{\prime \prime}$ & $20^{\circ} 16^{\prime} 24.10^{\prime \prime}$ & 1,719 & 7.5 & $22 \pm 13$ & $31 \pm 20$ & $0.9 \pm 0.6$ & 37 \\
\hline SK15 & NM & Tatra Mts SK & $49^{\circ} 13^{\prime} 59.08^{\prime \prime}$ & $20^{\circ} 12^{\prime} 46.00^{\prime \prime}$ & 1,650 & 7.5 & $65 \pm 29$ & $41 \pm 6$ & $1.8 \pm 0.2$ & 32 \\
\hline PL16 & $\mathrm{NM}$ & Tatra Mts PL & $49^{\circ} 13^{\prime} 54.00^{\prime \prime}$ & $19^{\circ} 54^{\prime} 38.17^{\prime \prime}$ & 2,090 & 7.0 & $144 \pm 62$ & $110 \pm 32$ & $3.5 \pm 1.2$ & 31 \\
\hline
\end{tabular}

The approximate age of included waste heaps from the heterogenetic Olkusz-Bolesław region is given in brackets in the third column $M$ metalliferous sites, $N M$ non-metalliferous sites, $E$ extractable form; $n a$ not available, $n$ number of genotypes per population

metalliferous and non-metalliferous according to the total $\mathrm{Zn}$ concentration in soil. Thereby, we considered $300 \mathrm{mgkg}^{-1}$ as the threshold concentration (Bert et al. 2002). Sample size varied from 28 to 37 individuals per location and distances between sites ranged from $1 \mathrm{~km}$ to more than $150 \mathrm{~km}$. Rhizospheric soil (5 samples per site) was sampled to a depth of $10 \mathrm{~cm}$ using a cylinder of $7 \mathrm{~cm}$ diameter. Soil $\mathrm{pH}$ was measured in distilled water by means of the potentiometric method (Wachalewski 1999). Total concentrations of $\mathrm{Zn}, \mathrm{Pb}$ and cadmium (Cd) were determined using atomic absorption spectrometry. The extractable fraction was determined by vortexing soil solution with EDTA (Escarré et al. 2000). Differences between average total concentrations of $\mathrm{Zn}, \mathrm{Pb}$ and $\mathrm{Cd}$, and their extractable fractions at metalliferous $v s$ non-metalliferous sites were tested by means of Student's $t$-test. The Bartlett test was performed to compare the homogeneity of variances between natural and anthropogenic sites.

\section{Molecular analysis}

The collected leaf material was dried for $24 \mathrm{~h}$ at $55^{\circ} \mathrm{C}$ prior to DNA extraction from 10 to $15 \mathrm{mg}$ of dry material using the NucleoSpin ${ }^{\circledR}$ 8/96 Plant kit
(Macherey-Nagel ${ }^{\circledR}$ ). PCR amplification was performed using 1:100 dilutions.

All individuals were genotyped using 9 microsatellite markers developed in B. neustriaca (Leducq et al. 2013) that we successfully transferred into $B$. laevigata. Several loci were amplified simultaneously and using forward primers labelled with Applied Biosystems dyes (multiplex 1: B6, B66, B45, B102, B146 and multiplex 2: B3, B24, B8, B26). Multiplexed PCR products were revealed using a 16-capillary $\mathrm{ABI} 3130$ sequencer (Applied Biosystems ${ }^{\circledR}$ ) with Gene-Scan 500 LIZ Size Standard (Applied Biosystems ${ }^{\circledR}$ ). The loci were scored using GeneMapper version 3.7 (Applied Biosystems ${ }^{\circledR}$ ).

Analyses of genetic structure and diversity

The mean allelic richness $\left(\mathrm{A}_{\mathrm{S}}\right)$ within each site was estimated over loci using FSTAT 2.9.3 (Goudet 2001). The rarefaction method (Kalinowski 2004) was used to standardize estimates to the smallest sample size $(n=28)$ collected from population PL1. The expected $\left(\mathrm{H}_{\mathrm{E}}\right)$ and observed $\left(\mathrm{H}_{\mathrm{O}}\right)$ heterozygosity as well as Wright's inbreeding coefficient $\left(\mathrm{F}_{\mathrm{IS}}\right)$ were estimated for each site using Genetix 4.05 (Laboratoire Génome et Populations, CNRS UPR 9060, Université de Montpellier II, Montpellier, France). Differences 
between edaphic types ( $\mathrm{M} v s \mathrm{NM}$ ) in average $\mathrm{A}_{\mathrm{S}}, \mathrm{H}_{\mathrm{E}}$ and $\mathrm{H}_{\mathrm{O}}$ were tested by means of Student's $t$-test. The level of genetic differentiation among edaphic types (M $v s \mathrm{NM}$ ) was estimated by means of hierarchical F statistic using the R-package HIERFSTAT (Goudet 2005). Differences between $\mathrm{M}$ and NM groups were tested using randomization procedures (1,000 permutations of populations between edaphic types).

We estimated the number of homogeneous gene pools $(\mathrm{K})$ that best explained the pattern of genetic structure at microsatellite loci using Bayesian modelbased clustering implemented in Structure 2.3.2 (Pritchard et al. 2000). Analyses were carried out under the admixture model, assuming an identical parameter of individual admixture across clusters and a uniform prior. For each $\mathrm{K}$ value within the range of $1-16$ we performed 10 independent runs with 100,000 iterations after a burn-in period of 10,000 generations, with no prior information on the origin of individuals. Finally, from the mean likelihood $\log _{e}(K)$ of replicates we computed the $\Delta \mathrm{K}$ statistics to identify the most likely number of clusters (Evanno et al. 2005). Additionally, a Neighbor-Joining (NJ) population tree was drawn from Cavalli-Sforza and Edwards chord distances, based on allele frequencies and using the TreeView software (http://taxonomy.zoology.gla.ac.uk/rod/treeview.html). The node robustness was evaluated using 10,000 bootstrapped replicates.

The contribution of geographic distances to differences in the genetic structure (isolation by distance patterns, IBD; Wright 1949) between populations was assessed by correlating the matrices of log-transformed geographic distances between pairs of populations and linearized pairwise genetic distances $\left(\mathrm{F}_{\mathrm{ST}} /\left(1-\mathrm{F}_{\mathrm{ST}}\right)\right.$ ) using a Mantel test (Mantel 1967). Pairwise $\mathrm{F}_{\mathrm{ST}}$ values were calculated using 1,000 random permutations of individuals in Genetix 4.05 (Laboratoire Génome et Populations, CNRS UPR 9060, Université de Montpellier II, Montpellier, France). Separate Mantel tests with 100,000 random permutations each were performed for the entire data set, as well as for the $\mathrm{M}$ and NM populations separately, using the R-package ade4 (Dray and Dufour 2007).

\section{Approximate Bayesian Computation (ABC) analysis}

A demographic scenario of divergence between $\mathrm{M}$ and NM populations was modeled and the simulated datasets were compared to observed data by means of an ABC approach (Beaumont et al. 2002). Three parameters were considered to describe the demographic model: effective population size of $\mathrm{M}\left(N_{M}\right)$, effective population size of NM $\left(N_{N M}\right)$, and divergence time in generations $\left(t_{\mathrm{G}}\right)$. Using the program DiyABC v2.0 (Cornuet et al. 2008), we simulated 500,000 multilocus datasets based on a demographic history that describes the model. For each simulation, the parameter values were drawn from their prior distributions. The uniform prior distributions were defined over the intervals $10-200,000$ for $N_{M}$ and $N_{N M}$, and $10-5,000$ for $\mathrm{t}_{\mathrm{G}}$. The mutation rate and the model for microsatellites were set to default. We generated distributions of 11 summary statistics of genetic diversity (mean number of alleles per locus: $A_{M}, A_{M}$; mean expected heterozygosity: $H_{e M}, H_{e N M}$; mean allele size variance: $V_{M}, V_{N M}$; $\mathrm{F}_{\mathrm{ST}}$ between pairs of population samples, classification index (also called mean individual assignment likelihood): $L I K_{M}, L I K_{N M}$; shared allele distance: $D A S ;(d \mu)^{2}$ distance between two samples) by coalescent-based simulations. The posterior distributions of the parameters for the model were estimated on the 2,000 replicate simulations with the smallest associated Euclidean distance $\left(\delta=\left\|S_{\text {obs }}-S_{\text {sim }}\right\|\right)$ using a non-linear regression after the application of a logit transformation on parameter values (Beaumont et al. 2002). Finally, following Cornuet et al. (2010), we employed the model-checking function of DiyABC to assess the goodness-of-fit between each model parameter -posterior combination and the observed dataset. Computations based on 1,000 simulated datasets and 13 summary statistics (i.e. $A, H_{e}, V$, mean $M_{G W}$ index (Garza-Williamson's M) across loci, $L I K, D A S,(d \mu)^{2}$ distance), generated a posterior cumulative distribution function for each statistic together with the estimated probability ( $P$ values) of these distributions to fit the original observations. A principal component analysis (PCA) was performed in the space of summary statistics, considering 5,000 datasets simulated with parameter values drawn from the prior. The observed dataset, as well as the 1,000 datasets simulated from the posterior distributions of parameters were passively projected into the PCA plane.

\section{Detection of recent bottlenecks}

We tested for a recent occurrence of bottlenecks in each of the 16 populations using Bottleneck 1.2.2 (Luikart 
et al. 1998) under a two-phase mutation model (TPM; Di Rienzo et al. 1994) and using 1,000 iterations. Three different percentages of mutations that follow a strict stepwise mutational $(\mathrm{SMM})$ process $\left(\mathrm{P}_{\mathrm{SMM}}=5 \%, 30 \%\right.$ and $60 \%$ ) and five values of the variance in size of multistep mutations $\left(\mathrm{V}_{\mathrm{TPM}}=2,4,9,16\right.$, and 25) were tested. The $\mathrm{V}_{\text {TPM }}$ were specified on the basis of the observed ranges of microsatellite allele sizes detected in our sampling (data not shown) and corresponded to average multistate mutational jumps of $\sim 1,2,3$, 4, or 5 steps (Di Rienzo et al. 1994). We used the following two criteria to detect bottlenecks: 1) significant deviation from mutation drift equilibrium $\left(\mathrm{H}_{0}=\right.$ none-bottleneck; $p<0.05$, sign test; Luikart and Cornuet 1998) and 2) high probability of heterozygosity excess $(p>0.5$, Wilcoxon sign-rank test; Luikart et al. 1998).

\section{Results}

Characterization of soil conditions

The sampling comprised nine (sub-)alpine nonmetalliferous locations (PL7-PL9, PL11-PL13, SK14, SK15, PL16), six metalliferous (PL1-PL6) locations at low altitude in the Bolesław - Olkusz region, and one non-metalliferous location (PL10) at low altitude in Zagórzyce (Małopolska Upland). Interestingly, total $\mathrm{Zn}$ concentration in the soil at PL16 slightly exceeded the threshold (300 $\mathrm{mg} \mathrm{kg}^{-1}$, Bert et al. 2002), indicating that some Tatra provenances of B. laevigata also experience naturally elevated metals levels. Total (and extractable) soil concentrations of $\mathrm{Zn}, \mathrm{Pb}$ and $\mathrm{Cd}$ varied considerably among sites and were on average 245,32 and $42(65,25$ and 40) times larger at metalliferous compared to non-metalliferous locations $(p<0.001, t$ test; Table 1; Table S1). In addition, the variance was significantly higher within the metalliferous compared to the non-metalliferous group ( $p<0.001$, Bartlett test).

Microsatellite diversity and population structure

All nine nuclear microsatellite loci investigated in this study were highly polymorphic, showing between 4 and 25 alleles per locus. Mean allelic richness $\left(\mathrm{A}_{\mathrm{S}}\right)$, observed $\left(\mathrm{H}_{\mathrm{O}}\right)$ and expected heterozygosity $\left(\mathrm{H}_{\mathrm{E}}\right)$ ranged from 4.506 to $8.872,0.284$ to 0.658 and 0.309 to 0.743 , respectively, and were significantly lower in $\mathrm{M} v s \mathrm{NM}$ populations ( $p<0.001, t$-test; Table 2$)$. The inbreeding
Table 2 Genetic variation within B. laevigata populations

\begin{tabular}{llllll}
\hline Pop & As & $\mathrm{H}_{\mathrm{O}}$ & $\mathrm{H}_{\mathrm{E}}$ & $\mathrm{F}_{\mathrm{IS}}$ & \\
\hline PL1 & 4.506 & 0.332 & 0.367 & 0.154 & $* * *$ \\
PL2 & 5.387 & 0.299 & 0.399 & 0.297 & $* * *$ \\
PL3 & 6.370 & 0.424 & 0.543 & 0.268 & $* * *$ \\
PL4 & 4.959 & 0.293 & 0.379 & 0.266 & $* * *$ \\
PL5 & 5.454 & 0.396 & 0.432 & 0.120 & $* * *$ \\
PL6 & 4.569 & 0.284 & 0.309 & 0.240 & $* * *$ \\
PL7 & 8.424 & 0.621 & 0.720 & 0.156 & $* * *$ \\
PL8 & 8.872 & 0.658 & 0.743 & 0.154 & $* * *$ \\
PL9 & 7.849 & 0.602 & 0.677 & 0.176 & $* * *$ \\
PL10 & 6.132 & 0.459 & 0.522 & 0.175 & $* *$ \\
PL11 & 6.042 & 0.516 & 0.604 & 0.141 & $* * *$ \\
PL12 & 8.326 & 0.572 & 0.708 & 0.198 & $* * *$ \\
PL13 & 7.084 & 0.538 & 0.701 & 0.240 & $* * *$ \\
SK14 & 8.024 & 0.499 & 0.698 & 0.286 & $* * *$ \\
SK15 & 8.146 & 0.544 & 0.664 & 0.180 & $* * *$ \\
PL16 & 8.566 & 0.577 & 0.721 & 0.192 & $* * *$ \\
\hline
\end{tabular}

$A_{S}$ allelic richness, $H_{O}$ observed heterozygosity, $H_{E}$ expected heterozygosity, $F_{I S}$ inbreeding coefficient and associated $\mathrm{p}$ value ${ }^{*} p \leq 0.05,{ }^{* *} p \leq 0.01,{ }^{* * *} p \leq 0.001$

coefficient $\left(\mathrm{F}_{\mathrm{IS}}\right)$ values were low, as expected for a selfincompatible species, but significantly higher than zero in all populations, which could relate to local biparental inbreeding. The level of genetic differentiation varied between populations, with a general tendency toward lower overall differentiation in $\mathrm{M}$ than in NM populations $(p<0.001, t$-test $)$.

Bayesian clustering, IBD patterns and $\mathrm{ABC}$ approach

Based on the highest modal value of the $\Delta \mathrm{K}$ statistics, the Bayesian clustering analysis revealed two sets of populations (Fig. S1). Considering $K=2$ as the real number of clusters, we observed a clear separation between populations from the metalliferous (cluster 1, C1) and non-metalliferous sites (cluster 2, C2; Fig. 2a). At $K=2$, distribution values $\left(Q_{J i}\right)$ were generally high and individuals from a given location were consistently assigned to a common gene pool. In some NM populations (in particular PL10, PL13-PL16), however, $Q_{J i}$ values were lower and heterogeneous for several individuals (samples were not clearly assigned to the cluster $\mathrm{C} 2$ ), suggesting admixture. The NJ tree further revealed the existence of two distinct genetic groups (Fig. 2b). 
(a)

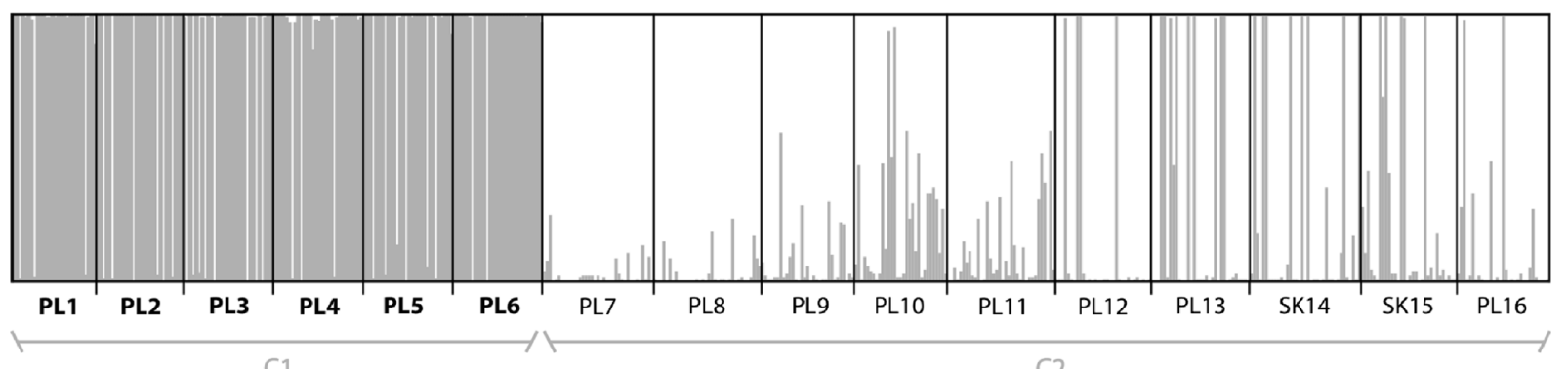

(b)

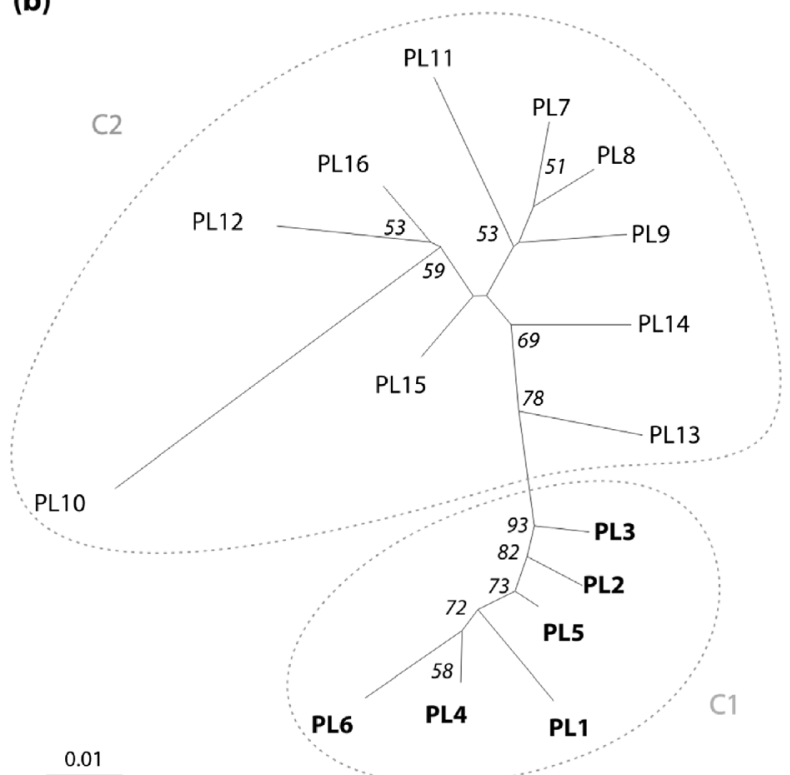

Fig. 2 a Bar plot showing clustering of individuals by STRUCTURE with $K=2$; b Neighbor-Joining population tree using the Cavalli-Sforza and Edwards distances. Bootstrap values (in percent from 10,000 replicates) are indicated with italics near

The inferred tree topologies were robust with most bootstrapped values greater $70 \%$.

We did not find significant patterns of isolation by distance (IBD) for pairwise comparisons among all investigated populations (Fig. S2, $r=-0.126, p=0.961$, Mantel test), suggesting no contribution of geographic distance to genetic structure among edaphic types. Similarly, no correlation between genetic and geographic distances was observed for pairwise comparisons among samples within the $\mathrm{M}$ group $(r=-0.288, p=$ 0.950). Within the entire NM group, the correlation was positive and significant $(r=0.881, p=0.021)$ but turned non-significant if the only lowland location

the branches (only values greater than $50 \%$ are shown). Metallicolous populations are marked in bold, non-metallicolous in normal font. $\mathrm{C} 1$ and $\mathrm{C} 2$ are the clusters of studied populations, according to their genetic distances

PL10 was removed from the analysis $(r=0.205, p=$ 0.236). Overall, this suggests that gene flow within clusters is not restricted by geographic distances among sites.

Assuming a simple scenario of demographic divergence between $\mathrm{M}$ and NM populations, we inferred the population history and dated the median time of divergence between $\mathrm{M}$ and $\mathrm{NM}$ populations $\left(\mathrm{t}_{\mathrm{G}}\right)$ back to 1,200 generations ago (Table 3 ). The median value of the mutation rate of SSR and SNI at the examined loci was estimated at $2.93 \times 10^{-4}$ and $4.56 \times 10^{-8}$, respectively. Differences between the prior and posterior density curves for all demographic parameters were pronounced 
Table 3 Mean, median, mode and quantiles of the posterior distribution sample for demographic parameters of the simulated data set (obtained by DiyABC with 500,000 of simulated data sets)

\begin{tabular}{llllll}
\hline Parameter & mean & median & mode & Quantile 2.5\% & Quantile 97.5\% \\
\hline$N_{M}$ & 5,510 & 4,960 & 4,460 & 1,370 & 12,500 \\
$N_{N M}$ & 89,900 & 81,000 & 40,900 & 14,200 & 192,000 \\
$\mathrm{t}_{\mathrm{G}}$ & 1,530 & 1,200 & 538 & 222 & 4,420 \\
Mutation rate of SSR & $3.61 \mathrm{E}-04$ & $2.93 \mathrm{E}-04$ & $1.49 \mathrm{E}-04$ & $1.14 \mathrm{E}-04$ & $9.09 \mathrm{E}-04$ \\
Mutation rate of SNI & $1.53 \mathrm{E}-07$ & $4.56 \mathrm{E}-08$ & $1.00 \mathrm{E}-08$ & $1.01 \mathrm{E}-08$ & $9.69 \mathrm{E}-07$ \\
\hline
\end{tabular}

$N_{M}$ effective population size of metallicolous (M) populations, $N_{N M}$ effective population size of non-metallicolous $(N M)$ populations, $\mathrm{t}_{\mathrm{G}}$ divergence time in generations

with clearly peaked posteriors (Fig. S3), indicating that the genetic data were informative for parameters under the proposed scenario. Observed values of the summary statistics did not significantly differ from the simulated values based on parameter values drawn from the posterior distributions for the tested scenario (data not shown). In the PCA, the observed data matched the values obtained from the posterior and prior distributions (data not shown), thus further indicating a good fit of the posterior distribution based on the tested scenario.

\section{Bottleneck detection}

All M populations except PL2 consistently indicated a recent bottleneck event (Table S2). By contrast, patterns detected in NM populations changed, depending on the implemented mutational models (varying $\mathrm{P}_{\mathrm{SMM}}$ and $\mathrm{V}_{\text {TPM }}$ values). In models with the lowest $\mathrm{V}_{\text {TPM }}$ values (corresponding to average multistate mutational jumps of $\sim 1,2$ and 3), some NM populations presented a pattern coherent with a mutation-drift equilibrium (PL7, PL8, PL13, PL16), while others exhibited a bottleneck signature (PL9, PL12, SK14 and SK15). If the highest $\mathrm{V}_{\mathrm{TPM}}$ values were considered, some NM populations (PL7, PL8, PL13, PL16) showed high probability of heterozygosity deficiency $(\mathrm{P}(\mathrm{Hd})>0.7$, Wilcoxon sign-rank test) suggesting a recent population expansion or the introduction of new alleles by immigrants.

\section{Discussion}

The present study highlights patterns of genetic diversity and population structure of all known $\mathrm{M}$ and NM populations of B. laevigata in Poland using nuclear microsatellite markers. This investigation showed that populations clustered into two groups which mainly reflected their edaphic origin. This remains true even considering the only lowland NM population (PL10) that was assigned to the geographically distant NM cluster of alpine sites.

In case of metallophytes, influences of edaphic conditions and soil metal contamination have often been shown to exceed the impact of geographic distance on genetic structure (Deng et al. 2007). Based on our results, similar trends can be proposed for B. laevigata, although this may not be fully conclusive in the absence of other lowland NM populations. Interestingly, an earlier investigation on a continuous tetraploid population of $B$. laevigata located in the Alps (Parisod and Christin 2008) similarly suggested that environmental rather than geographical conditions played a major role in shaping the genetic structure between alpine and subalpine habitats.

In contrast to multiple previous studies on pseudometallophytes, which failed to detect evidence for strong founder events in M populations (Pauwels et al. 2005 and references therein), our investigation suggested that the presence of genotypes in metal-contaminated environments is associated with genetic features supporting a founder effect in B. laevigata. Firstly, the genetic diversity observed in $\mathrm{M}$ populations was significantly lower compared to NM populations. Secondly, most M populations showed a strong and consistent bottleneck signal that was retained at all loci, suggesting recent demographic events (Luikart et al. 1998). Considering that anthropogenic habitats are also of recent origin, genetic results strongly suggest that the occurrence of $B$. laevigata in lowland locations in the Bolesław Olkusz region is associated with the colonization 
of metal-polluted sites. Moreover, the increased metal tolerance levels observed in $\mathrm{M}$ populations (Wierzbicka and Pielichowska 2004) also suggest that those populations experienced local adaptation to metal exposure, a phenomenon that could have further decreased genetic diversity. In summary, it appears that colonization of metal-polluted areas has been a dominant evolutionary driver of $B$. laevigata populations in southern Poland and has significantly modified the genetic structure of the species in recent times.

A recent colonization of the Bolesław - Olkusz region would suggest LDD event from the Tatra Mts. In addition, we did not observe any evidence for a general pattern of IBD (i.e. for the balance between gene flow and genetic drift; Hutchison and Templeton 1999), which is likely a consequence of the uneven habitat distribution in southern Poland. However, B. laevigata has no biological capacity of LDD of seeds (Parisod and Bonvin 2008), in particular considering that the investigated edaphic types are located more than $100 \mathrm{~km}$ apart. Still, we cannot fully exclude the occurrence of LDD in the species history, as some molecular studies have shown patterns of highly disjunctive distributions via LDD, even for taxa characterized by limited seed dispersal capacity (e.g. Escudero et al. 2010; Schönswetter et al. 2004; Tribsch et al. 2002). Moreover, LDD could have been favored by human activities. Indeed, as B. laevigata grows on metal-enriched sites in lowland areas, documented ore mining activities in the Tatra Mts (18th and 19th centuries; Landenberger et al. 2003) could have facilitated LDD towards metal enriched sites in Poland (e.g. moving miners or material transport). Such potential anthropogenic seed transport could at least partly explain the admixture signals that we observed within the NM ecotype, as the spontaneous hybridization between $\mathrm{M}$ and NM groups seems unlikely in light of the geographic isolation of these two genetically divergent clusters. An alternative explanation for admixed populations is an incomplete lineage sorting, which may still be ongoing due to the longevity of B. laevigata and its capacity to reproduce via vegetative propagation.

As an alternative scenario to recent $\mathrm{LDD}, \mathrm{ABC}$ results suggest that the divergence between $M$ and NM populations is ancient. Assuming a generation turnover in B. laevigata of 10 to 100 years (Ch. Parisod, personal communication), we roughly dated the divergence time (1,200 generations ago) of $\mathrm{M}$ and NM populations between 12 and 120,000 years before present (BP), suggesting that the populations that colonized metalliferous lowland sites may indeed predate the LGM (2026,000 years BP, Clark et al. 2009). The calcareous slopes and cliffs of the Tatra Mts offer suitable habitats for $B$. laevigata and probably served as refugia for this and other montane taxa during the glaciations. This is consistent with the interglacial or even pre-glacial relic character of other diploid populations of $B$. laevigata from Central Europe (Manton 1934; Tremetsberger et al. 2002). The co-occurrence of two genetic clusters of $B$. laevigata in our study could thus be explained by well-known profound perturbations of the European flora during the last glaciation (Sánchez Goñi et al. 2005), which are considered the principal cause of geographically disjunctive species distributions at both continental and local scales (Bettin et al. 2007; Hewitt 1999, 2000; Kropf et al. 2006; Taberlet and Cheddadi 2002). This would rather suggest that the occurrence of $B$. laevigata in the Bolesław - Olkusz region largely predates the development of mining and industrial activities from the Middle Ages. This is in accordance with palaeobotanical studies conducted $50 \mathrm{~km}$ from the Bolesław - Olkusz region that suggested that, together with other mountain species, current lowland populations of $B$. laevigata are remnant of local pre-glaciation populations (Szafer 1930). Under such an assumption, the intriguing disjunctive distribution of $B$. laevigata in Poland would result from a fragmentation of species range during the Holocene, rather than LDD events.

Biscutella laevigata is regarded as a pioneer and shade-intolerant species poorly competing with other plant species (Dannemann 2000; Oberdorfer 2001). Its ecological affinities have apparently facilitated the colonization of metalliferous habitats, which recently became anthropogenic refugia for lowland populations. Based on our results (genotyping and soil metal concentrations) we assume that contrasted combinations of environmental constraints at metal-polluted sites may result in varying grades of selection pressure and require specific genotypic adaptation. Such site conditions continue to affect establishing populations of $B$. laevigata. Similar patterns were recently shown in another pseudometallophyte Viola tricolor from the Bolesław - Olkusz area (Słomka et al. 2011), where the existence of two genetic ecotypes among waste heap populations appears to be associated with an unequal horizontal and vertical distribution of metals in the soil. 


\section{Conclusions}

This study on the genetic structure and divergence of all known $\mathrm{M}$ and NM populations of B. laevigata in Poland has shown that the lowland populations are probably relic of previously well-established populations that had a larger distribution range prior to the LGM. This old vicariance between geographically separated lowland (mostly $\mathrm{M}$ ) and alpine (NM) populations continues to be modified by the ongoing microevolution processes caused by variable selective pressures at mosaic-like metal-contaminated sites. Interestingly, environmental conditions - in particular metal concentrations in the soil - appear to more strongly influence the genetic structure than geographic distance. A significant reduction in the genetic diversity (founder and bottleneck effects) in $\mathrm{M}$ compared to NM populations was associated with the colonization of polluted sites and/or evolution of M populations. As a consequence, populations from natural and anthropogenic locations have adapted to different environmental conditions and have genetically diverged. Hence, they should be considered as two distinct edaphic ecotypes. Our study emphasizes the importance of combined natural and anthropogenic historical impacts on the microevolution of $M$ populations, which need to be considered in future investigations of pseudometallophytes. Given the clear patterns of genetic divergence identified in our study, the $\mathrm{M}$ and NM populations of $B$. laevigata from southern Poland represent particularly interesting cases for analyzing the specific contributions of environmental and anthropogenic drivers of microevolution to the emergence of adapted ecotypes.

Acknowledgments The authors would like to thank to Flurin Babst for fruitful discussions and comments on the manuscript. We are grateful to Urszula Korzeniak and Zbigniew Kostecki for their help in the field, to Ewa Budziakowska-Kubik for technical assistance and to Chris Guiterman for polishing the text. The Tatra National Park is acknowledged for granting permits to collect plant samples within the park boundaries. This research was funded by the Polish Ministry of Science and Higher Education (grant no. N N304 370938). ABK further acknowledges funding from a Program for Young Scientists and PhD Students (Polish Ministry of Science and Higher Education via IB PAN internal grants, project no. $1 / 2013)$.

Open Access This article is distributed under the terms of the Creative Commons Attribution License which permits any use, distribution, and reproduction in any medium, provided the original author(s) and the source are credited.

\section{References}

Antonovics J, Bradshaw AD, Turner RG (1971) Heavy metal tolerance in plants. Adv Ecol Res 7:1-85

Assunção AGL, Bookum WM, Nelissen HJM, Vooijs R, Schat H, Ernst WHO (2003) Differential metal-specific tolerance and accumulation patterns among Thlaspi caerulescens populations originating from different soil types. New Phytol 159:411-419

Baumbach H, Hellwig FH (2007) Genetic differentiation of metallicolous and non-metallicolous Armeria maritima (Mill.) Willd. taxa (Plumbaginaceae) in Central Europe. Plant Syst Evol 269:245-258

Beaumont MA, Zhang W, Balding DJ (2002) Approximate Bayesian computation in population genetics. Genetics 162: 2025-2035

Bert V, Bonnin I, Saumitou-Laprade P, de Laguérie P, Petit D (2002) Do Arabidopsis halleri from nonmetalicolous populations accumulate zinc and cadmium more effectively than those from metallicolous populations? New Phytol 155:47-57

Bettin O, Cornejo C, Edwards PJ, Holderegger R (2007) Phylogeography of the high alpine plant Senecio halleri (Asteraceae) in the European Alps: in situ glacial survival with postglacial stepwise dispersal into peripheral areas. Mol Ecol 16:2517-2524

Bickham JW, Sandhu S, Hebert PDN, Chikhi L, Athwal R (2000) Effects of chemical contaminants on genetic diversity in natural populations: implications for biomonitoring and ecotoxicology. Mutat Res 463:33-51

Bizoux JP, Daïnou K, Raspé O, Lutts S, Mahy G (2008) Fitness and genetic variation of Viola calaminaria, an endemic metallophyte: implications of population structure and history. Plant Biol 10:684-693

Cabala J, Krupa P, Misz-Kennan M (2009) Heavy metals in Mycorrhizal Rhizospheres contaminated $\mathrm{By} \mathrm{Zn}-\mathrm{Pb}$ mining and smelting around Olkusz in Southern Poland. Water Air Soil Pollut 199:139-149

Clark PU, Dyke AS, Shakun JD et al (2009) The last glacial maximum. Science 325:710-714

Cornuet J-M, Ravigne V, Estoup A (2010) Inference on population history and model checking using DNA sequence and microsatellite data with the software DIYABC (v1.0). BMC Bioinformatics:11-401

Cornuet JM, Santos F, Beaumont MA et al (2008) Inferring population history with DIY ABC: a user-friendly approach to approximate Bayesian computation. Bioinformatics 24(23):2713-2719

Dannemann A (2000) Der Einfluss von Fragmentierung und Populationsgröße auf die genetische Variation und Fitness von seltenen Pflanzenarten am Beispiel von Biscutella laevigata (Brassicaceae). Dissertationes Botanicae, Stuttgart

Deng J, Liao B, Ye M, Deng D, Lan C, Shu W (2007) The effects of heavy metal pollution on genetic diversity in zinc/cadmium hyperaccumulator Sedum alfredii populations. Plant Soil 297:83-92

Di Rienzo A, Peterson AC, Garza JC, Valdes AM, Slatkin M, Freimer NB (1994) Mutational processes of simple-sequence repeat loci in human populations. Proc Natl Acad Sci U S A 91:3166-3170

Dray S, Dufour AB (2007) The ade4 package: implementing the duality diagram for ecologists. J Stat Softw 22:1-20 
Ernst WHO (2006) Evolution of metal tolerance in higher plants. For Snow Landsc Res 80:251-274

Ernst WHO, Schat HS, Verkleij JAC (1990) Evolutionary biology of metal resistance in Silene vulgaris. Evol Trend Plant 4:45-51

Escarré J, Lefèbvre C, Gruber W, Leblanc M, Lepart J, Rivière Y, Delay B (2000) Zinc and Cadmium hyperaccumulation by Thlaspi caerulescens from metalliferous and nonmetalliferous sites in the Mediterranean area: implications for phytoremediation. New Phytol 145:429-437

Escudero M, Valcárcel V, Vargas P, Luceño M (2010) Bipolar disjunctions in Carex: long-distance dispersal, vicariance, or parallel evolution? Flora Morphol Distrib Funct Ecol Plant 205:118-127

Evanno G, Regnaut S, Goudet J (2005) Detecting the number of clusters of individuals using the software STRUCTURE: a simulation study. Mol Ecol 14:2611-2620

Gasser M (1986) Genetic-ecological investigations in Biscutella levigata L. Veroeffentlichungen Des Geobotanischen Institutes des ETH 86:7-86

Goudet J (2001) Fstat, a program to estimate and test gene diversities and fixation indices (version 2.9.3)

Goudet J (2005) HIERFSTAT, a package for R to compute and test hierarchical F-statistics. Mol Ecol Notes 5:184-186

Grodzinska K, Korzeniak U, Szarek-Lukaszewska G, Godzik B (2000) Colonization of zinc mine spoils in southern Poland preliminary studies on vegetation, seed rain and seed bank. Fragm Flor Geobot 45:123-145

Hewitt GM (1999) Post-glacial re-colonization of European biota. Biol J Linn Soc 68:87-112

Hewitt GM (2000) The genetic legacy of the Quaternary ice ages. Nature 405:907-913

Hutchison DW, Templeton AR (1999) Correlation of pair wise genetic and geographic distance measures: inferring the relative influences of gene flow and drift on the distribution of genetic variability. Evolution 53:1898-1914

Jalas J, Suominen J, Lampinen Re (1996) Atlas Florae Europaeae. Distribution of vascular plants in Europe. 11. Cruciferae (Ricotia to Raphanus). The committee for mapping the flora of Europe \& societas biologica fennica vanamo, Helsinki

Jędrzejczyk-Korycińska M (2006) Floristic diversity in calamine areas of the Silesia-Cracow Monocline. Biodivers Res Conserv 3-4:340-343

Kalinowski ST (2004) Counting alleles with rarefaction: private alleles and hierarchical sampling designs. Conserv Genet 5: 539-543

Kang SS, Chung MG (2000) High levels of allozyme variation within populations and low allozyme divergence within and among species of Hemerocallis (Liliaceae). Am J Bot 87: 1634-1646

Kropf M, Comes HP, Kadereit JW (2006) Long-distance dispersal vs vicariance: the origin and genetic diversity of alpine plants in the Spanish Sierra Nevada. New Phytol 172:169-184

Lambinon J, Auquier P (1964) La flore et la végétation des terrains calaminaires de la Wallonie septentrionale et de la Rhénanie aixoise. Types chorologiques et groupes écologiques. Natura mosana 16:113-130

Landenberger A, Kiebała A, Michalik M (2003) Heavy mineral assemblages from recent stream alluvia in the Tatra Mts. Pol Tow Mineral, Prace Spec 19:79-81

Leducq J-B, Cl S, Gosset C et al (2013) Intriguing small-scale spatial distribution of chloropastic and nuclear diversity in the endangered plant Biscutella neustriaca (Brassicaceae). Conserv Genet 14:65-77

Lefèbvre C, Vernet P (1990) Microevolutionary processes on contaminated deposits. In: Shaw J (ed) Heavy metal tolerance in plants: evolutionary aspects. CRC Press Inc, Boca Raton, pp 285-300

Linhart YB, Grant MC (1996) Evolutionary significance of local genetic differentiation in plants. Annu Rev Ecol Syst 27:237277

Luikart G, Cornuet J-M (1998) Empirical evaluation of a test for identifying recently bottlenecked populations from allele frequency data. Conserv Biol 12:228-237

Luikart G, Sherwin WB, Steele BM, Allendorf FW (1998) Usefulness of molecular markers for detecting population bottlenecks via monitoring genetic change. Mol Ecol 7: 963-974

Macnair MR (1987) Heavy metal tolerance in plants: a model evolutionary system. Trends Ecol Evol 2:354

Macnair MR, Tilstone GH, Smith SE (2000) The genetics of metal tolerance and accumulation in higher plants. In: Terry $\mathrm{N}$, Banuelos G, Vangronsveld J (eds) Phytoremediation of contaminated soil and water. CRC Press, Boca Raton, pp 235250

Mantel NA (1967) The detection of disease clustering and a general regression approach. Cancer Res 27:209-220

Manton I (1934) The Problem of Biscutella Laevigata L. Z. Indukt. Abstammungs- Vererbungsl. 67:41-57

Mengoni A, Barabesi C, Gonnelli C, Galardi F, Gabbrielli R, Bazzicalupo M (2001) Genetic diversity of heavy metaltolerant populations in Silene paradoxa L. (Caryophyllaceae): a chloroplast microsatellite analysis. Mol Ecol 10:1909-1916

Meyer C-L, Kostecka AA, Saumitou-Laprade P, Créach A, Castric V, Pauwels M, Frérot H (2010) Variability of zinc tolerance among and within populations of the pseudometallophyte Arabidopsis halleri and possible role of directional selection. New Phytol 185:130-142

Nordal I, Haraldsen KB, Ergon A, Eriksen AB (1999) Copper resistance and genetic diversity in Lychnis alpina (Caryophyllaceae) populations on mining sites. Folia Geobot 34:471-481

Oberdorfer E (2001) Pflanzensoziologische exkursionsflora. Folia geobotanica et phytotaxonomica. Ulmer Verlag, Stuttgart

Olowokudejo JD, Heywood VH (1984) Cytotaxonomy and breeding system of the genusBiscutella (Cruciferae). Plant Syst Evol 145:291-309

Parisod C, Bonvin G (2008) Fine-scale genetic structure and marginal processes in an expanding population of Biscutella laevigata L. (Brassicaceae). Heredity 101: 536-542

Parisod C, Christin PA (2008) Genome-wide association to finescale ecological heterogeneity within a continuous population of Biscutella laevigata (Brassicaceae). New Phytol 178: 436-447

Pauwels M, Frérot H, Bonnin I, Saumitou-Laprade P (2006) A broad-scale analysis of population differentiation for $\mathrm{Zn}$ tolerance in an emerging model species for tolerance study: Arabidopsis halleri (Brassicaceae). J Evol Biol 19:18381850

Pauwels M, Saumitou-Laprade P, Holl A-C, Petit D, Bonnin I (2005) Multiple origin of metallicolous populations of the 
pseudometallophyte Arabidopsis halleri (Brassicaceae) in Central Europe: the cpDNA testimony. Mol Ecol 14:44034414

Peralta-Videa JR, Lopez ML, Narayan M, Saupe G, GardeaTorresdey J (2009) The biochemistry of environmental heavy metal uptake by plants: implications for the food chain. Int $\mathrm{J}$ Biochem Cell B 41:1665-1677

Pošćić F, Marchiol L, Schat H (2013) Hyperaccumulation of thallium is population-specific and uncorrelated with caesium accumulation in the thallium hyperaccumulator, Biscutella laevigata. Plant Soil 365:81-91

Pritchard JK, Stephens M, Donnelly P (2000) Inference of population structure using multilocus genotype data. Genetics 155:945-959

Przemyski A, Piwowarczyk R (2012) Biscutella laevigata L. in the Polish uplands - new data on its distribution from nida basin. Botanica - Steciana:21-29

Sánchez Goñi MF, Loutre MF, Crucifix M et al (2005) Increasing vegetation and climate gradient in Western Europe over the Last Glacial Inception (122-110 ka): data-model comparison. Earth Planet Sci Lett 231:111-130

Schönswetter P, Tribsch A, Stehlik I, Niklfeld H (2004) Glacial history of high alpine Ranunculus glacialis (Ranunculaceae) in the European Alps in a comparative phylogeographical context. Biol J Linn Soc 81:183-195

Skalińska M (1950) Studies in chromosome numbers of Polish Angiosperms. Acta Soc Bot Pol 20:45-68

Słomka A, Sutkowska A, Szczepaniak M, Malec P, Mitka J, Kuta E (2011) Increased genetic diversity of Viola tricolor L. (Violaceae) in metal-polluted environments. Chemosphere $83: 435-442$

Szafer W (1930) Element górski we florze niżu polskiego (The mountain element in the flora of the Polish Plain) vol 29. Rozprawy Wydz. Mat.-Przyr. 69, dz.B, ser.III

Szarek-Łukaszewska G, Niklińska M (2002) Concentration of alkaline and heavy metals in Biscutella laevigata L. and Plantago lanceolata L. growing on calamine spoils (S Poland). Acta Biol Cracov Ser Bot 44:29-38

Taberlet P, Cheddadi R (2002) Ecology. Quaternary refugia and persistence of biodiversity. Science 297:2009-2010
Tremetsberger K, König C, Samuel R, Pinsker W, Stuessy TF (2002) Infraspecific genetic variation in Biscutella laevigata (Brassicaceae): new focus on Irene Manton's hypothesis. Plant Syst Evol:163-181

Tribsch A, Schonswetter P, Stuessy TF (2002) Saponaria Pumila (Caryophyllaceae) and the Ice Age in the European Alps. Am J Bot 89:2024-2033

Vekemans X, Hardy OJ (2004) New insights from fine-scale spatial genetic structure analyses in plant populations. Mol Ecol 13:921-935

Wąchalewski T (1999) Kwasowość czynna i potencjalna gleby [Activ and potential acidity of soil]. In: SzczepaniecCięciak E, Kościelniak P (eds) Chemia środowiska: ćwiczenia i seminaria, vol 2. Jagiellonian University, Krakow, pp 21-24

Wierzbicka M, Pielichowska M (2004) Adaptation of Biscutella laevigata L, a metal hyperaccumulator, to growth on a zinclead waste heap in southern Poland. I: differences between waste-heap and mountain populations. Chemosphere 54: 1663-1674

Wojcik M, Dresler S, Jawor E, Kowalczyk K, Tukiendorf A (2013) Morphological, physiological, and genetic variation between metallicolous and nonmetallicolous populations of Dianthus carthusianorum. Chemosphere 90:1249-1257

Wóycicki Z (1913) Obrazy roślinności Królestwa Polskiego (Vegetationsbilder aus dem Koenigreich Polen). Roślinność terenów galmanowych Bolesławia i Olkusza (Flora der Galmeigebiete von Bolesław und Olkusz). Kasa Mianowskiego, Warszawa, pp 1-33

Wright S (1949) The genetical structure of populations. Ann Hum Genet 15:323-354

Wu L (1990) Colonization and establishment of plants in contaminated sites. In: Shaw AJ (ed) Heavy metal tolerance in plants: evolutionary aspects. CRC Press, Boca Raton, pp 269-284

Ye M, Liao B, Li JT, Mengoni A, Hu M, Luo WC, Shu WS (2012) Contrasting patterns of genetic divergence in two sympatric pseudo-metallophytes: rumex acetosa L. and Commelina communis L. BMC Evol Biol 12:84-97

Zając M (1996) Mountain vascular plants in the polish lowlands. Pollut Bot Stud 11:1-92 